\title{
Contribution Index Based on Green Building Certification Systems
}

\author{
Yuting Sun and Bee Hua Goh \\ Department of Building, School of Design and Environment, National University of Singapore
}

\begin{abstract}
Green Building Certification Systems (GBCS) are carried out in many countries due to the rising awareness of the importance of sustainability in the building industry. The intention should have motivated participants to construct and operate buildings sustainably, however, there is not yet a method developed to investigate the motivation of the participants. Based on the GBCS, this paper proposes the contribution index as a standard global method to analyze the performance of participants in the green building industry. Three contribution indices, namely Frequency Contribution Index (FCI), Intensity Contribution Index (ICI) and Comprehensive Contribution Index (CCI) that concern each different category of participant, have been formulated. Three further analyses based on the index were undertaken to investigate some features of the industry. A case study of Singapore was conducted to show how the contribution index could be used to extract industry patterns and trends and assess the participants' performance in the green building industry. Interviews with experts provide some suggested applications and support for the findings.
\end{abstract}

Keywords: Green building, sustainable development, certification system, contribution index, performance assessment.

Paper type: Research article

\section{Introduction}

Promoting a sustainable building industry has become an important issue for both developing and developed countries currently due to the industry's large energy consumption and long period of operation (Wong et al., 2010). Different countries have designed certification systems for "Green Building" or "Sustainable Building", terms widely used to describe resource-efficient, environmentally friendly buildings (Kibert, 2008). These green building certification systems have contained requirements for saving energy, reducing waste and limiting pollution of buildings in order to encourage developers, clients, main contractors and other participants to adopt green technologies and sustainability considerations in decision-making.

Launched in the UK in 1990, the Building Research Establishment Environmental Assessment Method (BREEAM) is one of the oldest and most widely used assessment and certification

Copyright: Construction Economics and Building 2015. (C) 2015 Yuting Sun and Bee Hua Goh. This is an Open Access article distributed under the terms of the Creative Commons Attribution 4.0 Unported (CC BY 4.0) License (https://creativecommons.org/licenses/by/4.0/), allowing third parties to copy and redistribute the material in any medium or format and to remix, transform, and build upon the material for any purpose, even commercially, provided the original work is properly cited and states its license.

Citation: Sun, Y. and Goh, B.H., 2015. Contribution index based on green building certification systems, Construction Economics and Building, 15(2), 31-48. DOI: http://dx.doi.org/10.5130/AJCEB.v15i2.4348

Corresponding author: Yuting Sun; Email - bdgsunyu@nus.edu.sg

Publisher: University of Technology Sydney (UTS) ePress 
systems for sustainable building (Lee and Burnett, 2008; Kubba, 2012). It leads participants to design with the concept of low environmental impact and minimize the energy demands of a building (BRE Global Ltd., 2014). Similarly, Green Star is Australia's rating tool for the design and construction of sustainable buildings (Love et al., 2012) that include apartment buildings, schools, hospitals, offices, shopping centres and industrial facilities. Green Star also applies in South Africa, with some adjustments (GBSCA, 2014). Known for its high-level performance in the construction industry, Japan introduced the Comprehensive Assessment System for Built Environment Efficiency (CASEBEE), which consists of four main assessment tools; pre-design, new construction, existing building and renovation (Kubba, 2012), for the evaluation of different stages of a building project. Taking a leading role in green building in Asia where urbanization is developing rapidly (Ives, 2013), Singapore is trying to keep a balance between economic growth and environmental sustainability (Chew, 2010). The Building and Construction Authority (BCA) launched the Green Mark Scheme in 2005 as Singapore's national standard for green building certification (BCA, 2005). As one of the largest building markets, China applied Green Building Label (GBL) across the country (Ye et al., 2013). Leadership in Energy and Environment Design (LEED), another widely known assessment system for sustainable building, was introduced in the USA in 1998 (Kibert, 2008). It includes a series of systems for different types and stages of buildings (Tatari and Kucukvar, 2011) such as new construction, existing building operations, homes and others. In addition, LEED has been adopted by India (IGBC, 2014), Brazil (GBCBrasil, 2014) and Canada (CaGBC, 2014) for green building certification. In Russia, the Green Building Council is proposing both LEED and BREEAM (RuGBC, 2014) as its standard.

The intention of promoting the GBCS is to motivate participants, clients for instance, in the building industry to develop more environmentally friendly building projects (Kauffman, 2006). The method of creation and use of GBCS is important in achieving the goal. Creation of the GBCS refers to the construction of the certification process including criteria, scoring methods and others. It is vital to carry out a reasonable and comprehensive assessment tool to provide companies guidance in qualifying green buildings (Ali and Nsairat, 2009). Researchers have been addressing problems regarding this process. Though the green building assessment tools are designed to be comprehensive (Cole, 1999), the exclusion of total cost has raised doubts regarding their adequacy as design tools (Soebarto and Willamson, 2001). Siew, Balatbat and Carmichael (2013) summarized that the GBCS paid insufficient attention to the differentiation between projects and published reasoning for scores allocation. Furthermore, Ding (2008) claimed that the main obstacles that prevented acceptance of GBCS were inflexibility, complexity and inadequate consideration of a weighting system. Baird (2009) proposed to incorporate user performance criteria in the GBCS as most of them tended to concentrate on technical aspects such as energy efficiency. In addition, Cole (1999) mentioned the importance of customized performance issues in the assessment tools in order to account for consideration of variations in regions or buildings.

After the certification, a complementary process of using the GBCS to award companies in recognition of their green efforts would motivate them to take environmentally responsible actions (Kauffman, 2006). Launched in Singapore in 2008, was the Green Mark Champion Award for developers that attained a certain number of Green Mark certified buildings (Green Mark, 2014). The Best of Building Awards by US Green Building Council recognizes the best green products, projects, organizations and individuals (USGBC, 2014). BREEAM Awards will also be granted to some buildings, companies, countries and people each year in recognition of excellent 
performance in sustainable development in the building industry (BRE Global Ltd., 2014). However, the criteria of some awards may be not reasonable or justified in evaluating a company's contribution to the green building industry. For example, some awards may merely focus on the number of green buildings a company has participated in, compared to no award for a client building only one landmark project utilising leading green technology and outstanding performance on sustainability. As a result, it may discourage companies from continually improving the sustainability of their buildings. But the solutions for the problem have not been discussed in-depth by researchers. To addresses this challenge, this research proposes the development and use of a composite index based on the GBCS, to evaluate companies' green efforts in the building industry.

\section{Composite Index for Comprehensive Assessment}

The composite index is a mathematical methodology that aggregates a set of indicators (Saisana and Tarantola, 2002), and is increasingly recognized as a practical method in policy analysis and public communication for simple comparisons of performance. The comparisons can illustrate complicated and sometimes elusive issues in wide-ranging fields (Nardo et al., 2005), for example environment (Rogge, 2012), economy (Holt, Olomolaiye and Harris, 1994; Raab and Kotamraju, 2006) or society (Sagar and Najam, 1998; O’Hare and Gutierrez, 2012). In the building industry composite indices have been applied for general assessment such as building performance (Shohet, 2003), selection of contractors (Holt, Olomolaiye and Harris, 1994), project planning (Chu et al., 2014) and others.

To construct the composite index, researchers often adopt the weighted average of all the indicators by carrying out a certain weight for each indicator (Holt, Olomolaiye and Harris, 1994; Shohet, 2003; Nardo et al. 2005; Chu et al., 2014). Holt, Olomolaiye and Harris (1994) ranked the main factors that influenced clients' choice of contractor by the weight index. Two indicators, namely, importance response (IR) and problem response (PR), were measured through surveys. Equal weights for the two indicators formulated the weight index. Shohet (2003) proposed the Building Performance Indicator (BPI) as a systematic methodology to evaluate the condition of buildings. The indicator was composed of weighted average of the performance levels for ten building systems. The weight of each system was determined by its respective proportion in the building's life cycle cost. In addition, Chu et al. (2014) built a model for the life-cycle assessment of green buildings. The model was based on the Project Definition Rating Index (PDRI). Composite indicators such as project strategy, design, cost plan and others were incorporated into the index with scores as their weights.

\section{Indicators for the Assessment of Companies' Green Efforts}

The number of green buildings that one company has participated in and their levels of certification were considered as the selection criteria of some awards for the recognition of companies' green contribution (BRE Global Ltd., 2014; Green Mark, 2014; USGBC, 2014). Gross floor area (GFA) is often used to calculate the energy consumption per $\mathrm{m} 2$ in the assessment of energy efficiency (Deng and Burnett, 2000; Paul and Taylor, 2008). Therefore, it can be inferred 
that a building with larger GFA is likely to save more energy than others at the same level of energy efficiency. The total energy saved by a company and the sustainable space it has built should be considered in the evaluation. Moreover, green management has also been emphasised by researchers as proof of companies' efforts towards achieving sustainability, for example, to incorporate the concept of sustainability into the culture of a company or set up an individual team focusing on its green performance (Gabzdylova, Raffensperger and Castka, 2009; Hakkinen and Belloni, 2011). Considered for the assessment of companies' green efforts in this study were three indicators - quantity, space and quality. The 'quantity' indicator is represented by the number of green buildings that one company has taken part in; the 'space' indicator, expressed by GFA, refers to the green space a company has created; the 'quality' of a green building measures how environmentally friendly the building is, and is determined according to the level of green building certification. Considered to maintain a better 'quality' is a building with a higher level of certification than one with a lower level of certification.

\section{Methodology}

\section{Overview}

The aim of this paper is to introduce an index that can assess the contributions of participants in the green building industry within a certain region or country where a single GBCS is adopted. 'Participants' refer to the main category of entities that have taken part in a building project, including clients, main contractors, architectural consultant companies, Mechanical \& Electrical (M\&E) consultant companies, structural consultant companies, quantity surveyors and others. The weighted average of all the indicators was incorporated in the formulas to construct the contribution index. Analyses based on the index were made to gather some findings of the whole green building market. Interviews were conducted for the validation of contribution index and relative findings.

\section{Data Collection}

It is possible to extract quantity and space indicator data from a full list of all the certified green buildings, with information regarding participating companies, certification level and GFA. Only buildings constructed within the target region or country were included in the list.

The score ranges and weights for different levels of major GBCS are listed in Table 1. The middle scores of each certification level represent the quality indicators, specifically, the weights in Table 1. The default highest score for the top certification level is assumed to be 100. The weights in Table 1 are based on the general score ranges in the GBCS. Construction of the index is regardless of buildings types and applied for multiple types of buildings as long as the weights are consistent. If the score range of a certain building types is different from the general range in Table 1, conversion rates between them need to be confirmed for consistency. 
Table 1: Score ranges and weights for each level of green building in major GBCS

\begin{tabular}{|c|c|c|c|c|c|c|}
\hline GBCS & Country/Region & $\begin{array}{l}\text { Year } \\
\text { Started }\end{array}$ & $\begin{array}{l}\text { Certification } \\
\text { Categories }\end{array}$ & $\begin{array}{l}\text { Level } \\
\mathrm{S} / \mathrm{N}\end{array}$ & $\begin{array}{l}\text { Score } \\
\text { range }\end{array}$ & Weight \\
\hline \multirow{5}{*}{$\begin{array}{l}\text { BREEAM } \\
\text { (BRE Global Ltd., } \\
\text { 2011) }\end{array}$} & \multirow{5}{*}{$\begin{array}{l}\text { UK, Russia, Germany, } \\
\text { Spain, Norway, } \\
\text { Sweden, Netherlands, } \\
\text { Austria }\end{array}$} & 1990 & Pass & 1 & $>30$ & 37.50 \\
\hline & & & Good & 2 & $>45$ & 50.00 \\
\hline & & & Very Good & 3 & $>55$ & 62.50 \\
\hline & & & Excellent & 4 & $>70$ & 77.50 \\
\hline & & & Outstanding & 5 & $>85$ & 92.50 \\
\hline \multirow{4}{*}{$\begin{array}{l}\text { HK-BEAM } \\
\text { (BEAM Society Ltd., } \\
\text { 2012) }\end{array}$} & \multirow{4}{*}{ China (Hong Kong) } & 1996 & Bronze & 1 & $40 \%$ & 47.50 \\
\hline & & & Silver & 2 & $55 \%$ & 60.00 \\
\hline & & & Gold & 3 & $65 \%$ & 70.00 \\
\hline & & & Platinum & 4 & $75 \%$ & 87.50 \\
\hline \multirow{4}{*}{$\begin{array}{l}\text { LEED } \\
\text { (USGBC, 2009) }\end{array}$} & \multirow{4}{*}{$\begin{array}{l}\text { USA, Canada, Russia, } \\
\text { India, Brazil }\end{array}$} & 1998 & Certified & 1 & $40-49$ & 45.00 \\
\hline & & & Silver & 2 & $50-59$ & 55.00 \\
\hline & & & Gold & 3 & $60-79$ & 70.00 \\
\hline & & & Platinum & 4 & $>=80$ & 90.00 \\
\hline \multirow{3}{*}{$\begin{array}{l}\text { Green Star } \\
(\text { GBCA, 2012) }\end{array}$} & \multirow{3}{*}{ Australia, South Africa } & 2003 & Best Practice & 1 & $45-59$ & 52.50 \\
\hline & & & Au Excellence & 2 & $60-74$ & 67.50 \\
\hline & & & World Leader & 3 & $>=75$ & 87.50 \\
\hline \multirow{4}{*}{$\begin{array}{l}\text { Green Mark } \\
(B C A, 2010 b)\end{array}$} & \multirow{4}{*}{ Singapore } & 2005 & Certified & 1 & $50-75$ & 62.50 \\
\hline & & & Gold & 2 & $75-85$ & 80.00 \\
\hline & & & Gold Plus & 3 & $85-90$ & 87.50 \\
\hline & & & Platinum & 4 & $>=90$ & 95.00 \\
\hline \multirow{3}{*}{$\begin{array}{l}\text { Green Building Label } \\
\text { (MHURD, 2014) }\end{array}$} & \multirow{3}{*}{ China (Mainland) } & 2007 & One Star & 1 & $50-60$ & 55.00 \\
\hline & & & Two Star & 2 & $60-80$ & 70.00 \\
\hline & & & Three Star & 3 & $>=80$ & 90.00 \\
\hline
\end{tabular}

\section{Constructing the Contribution Index}

The proposed formulas are as follows:

Frequency Contribution Index (FCI) shows how frequency of participation in environmentally friendly buildings. It measures both the quantity and quality of the certified green buildings that a company has built.

$$
F C I_{k}=\frac{\sum_{i=1}^{n} W_{i} N_{i k}}{\sum_{i=1}^{n} W_{i} N_{i}}
$$

Where:

$F C I_{k}$ - Frequency Contribution Index of company $k$

$W_{i}$ - weight of green building certification level $i$ 
$N_{i k}$ - number of buildings, under company $k$, with green building certification at level $i$

$N_{i}$ - number of buildings, under all the companies, with green building certification at level $i$

$i$ - green building certification level

$n$ - total number of green building certification levels in a certain GBCS

Intensity Contribution Index (ICI) defines how much the participant contributes in this sustainable development effort. It measures both the space and quality of the certified green buildings a company has built. It is expressed as follows:

$$
I C I_{k}=\frac{\sum_{i=1}^{n} W_{i} S_{i k}}{\sum_{i=1}^{n} W_{i} S_{i}}
$$

Where:

$I C I_{k}$ - Intensity Contribution Index of company $\mathrm{k}$

$W_{i}$ - weight of green building certification level i

$S_{i k}$ - total GFA of buildings, under company $k$, with green building certification at level i

$S_{i}$ - total GFA of buildings, under all the companies, with green building certification at level i

$i$ - green building certification level

$n$ - total number of certification levels in a certain GBCS

Comprehensive Contribution Index (CCI) is the integrated index that describes the contribution percentage of each company with respect to the quantity, space and quality. The CCI is expressed as follows:

$$
C C I_{k}=\alpha \cdot F C I_{k}+\beta \cdot I C I_{k}
$$

Where:

$\alpha+\beta=1$

$C C I_{k}$ - Comprehensive Contribution Index of company $k$

$\mathrm{FCI}_{k}$ - Frequency Contribution Index of company $k$

$I C I_{k^{-}}$Intensity Contribution Index of company $k$

$\alpha$-weight of Frequency Contribution Index

$\beta$ - weight of Intensity Contribution Index

$\alpha$ and $\beta$ can be adjusted and then confirmed according to the user's requirement, preference and experience. The default $\alpha$ and $\beta$ are both 0.5 as an equal significance for the two indicators. The case study used the default values.

\section{Analysis based on the Contribution Index at Company Level}

Three analyses based on the index were conducted for further applications.

Cumulative contribution versus proportion of companies

A ranking list for a certain type of participant based on companies' CCI can be carried out. The cumulative CCI can be obtained by adding the individual CCI from the highest to the lowest. Then the proportion of companies (as $\mathrm{X}$ axis) and their cumulative CCI (as Y axis) can be displayed on a curve to show the relationship. The slope of the curve can show the rate of CCI's accumulation. The cumulative CCI for all companies is 100 percent. 


\section{Scatter plot of FCI and ICI}

A Scatter plot drawn with FCI as X axis and ICI as Y axis was used to show the distributions of all companies' FCI and ICI for a certain type of participant (see Figure 1). The whole area was divided into four equivalent zones by drawing a cross at the midpoints of maximum FIC and maximum ICI.

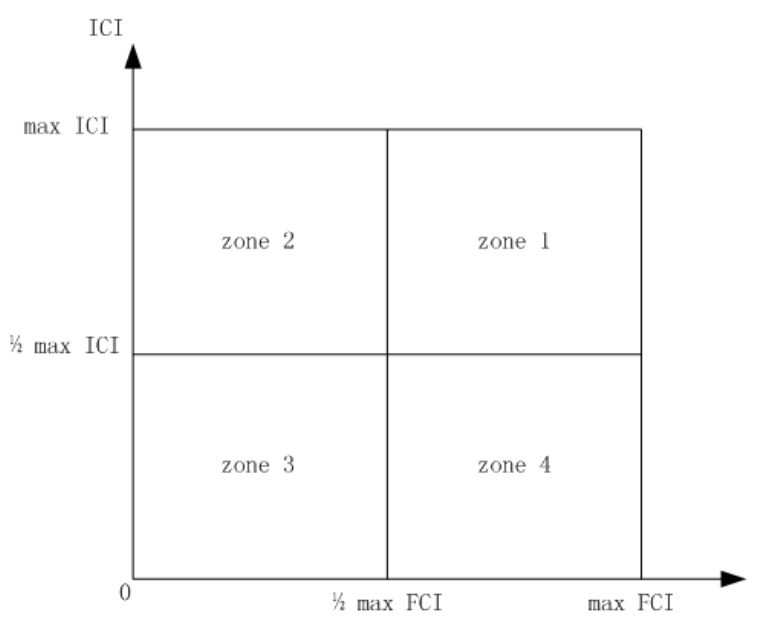

Figure 1: Scatter plot and arrangements of zones for FCI and ICI distribution

Four kinds of companies can be identified according to the zones they belong to. Companies in the four zones have either higher or lower FCI and ICI. The companies with higher ICI usually perform better while being assessed with the number of their green buildings and related certification levels. The companies with a higher FCI usually have done better with considerations of the total green space they create and the related certification levels. A lower ICI and lower FCI would mean the contrary. The combination of every two explanations among the four, namely, higher FCI, higher ICI, lower FCI and lower ICI, can show the features of companies in four zones.

\section{Analysis of the companies with higher contributions}

Companies with higher CCI are the leading ones that have put more effort into the sustainability of buildings. The analysis of the features of these companies, such as home country, size, and the major building types they are focusing on, is a good way to explore trends in the industry and their effect on the industry. The selection of features depends on the questions researchers want to investigate and the actual industry situation where the index is applied.

\section{Case Study of Singapore}

Singapore launched a national green building certification system called Green Mark (GM) scheme in 2005. Each year, the Building and Construction Authority (BCA), the official organizer of the scheme, will announce awards in four certification levels; Platinum, Gold Plus, Gold and Certified (Green Mark, 2014).

Although both residential and non-residential buildings are considered in the scheme, only non-residential buildings were selected because most residential buildings are built by the 
Housing \& Development Board (HDB) in Singapore. HDB currently provides housing for about 82 percent of the residents in Singapore (HDB, 2014). The non-residential building sector is more open to participation by both public and private companies. Selecting non-residential buildings to construct the contribution index would be more meaningful for ranking and comparison purposes. Four participant types that have a greater influence on the sustainability of a building project were selected. They are clients, main contractors, architectural consultant companies and M\&E consultant companies.

For data collection, a list of all the 337 non-residential buildings awarded the GM from 2005 to 2012 were collected and used. Relevant data was extracted from the annual report on Green Mark Scheme(BCA, 2005; BCA, 2006; BCA, 2007; BCA, 2008; BCA, 2009; BCA, 2010a; BCA, 2011; BCA, 2012) and the official website (Green Mark, 2014). However, for some projects, information for some participants or GFA was not available. In order to attain a certain percentage of complete samples, all the projects that contain the information of a type of participant were selected to construct the contribution index for that type, regardless of whether the information of other types of participants was available or not. The projects without GFA information were also omitted. Therefore, the four categories of participants have different numbers of samples as shown in Table 2.

Table 2: Number of Samples for each category of participants

\begin{tabular}{|lcc|}
\multicolumn{1}{c}{ Participant Category } & No. of Samples & Percentage (\%) \\
\hline Clients & 317 & 94.07 \\
\hline Architectural Consultant Companies & 268 & 79.53 \\
\hline Main Contractors & 241 & 71.51 \\
\hline M\&E Consultant Companies & 267 & 79.23 \\
\hline
\end{tabular}

The number of samples for each category of participant exceeds $70 \%$ of the total 337 buildings certified. The three contribution indices of a company were calculated based on the formulas of FCI, ICI and CCI. The three previously mentioned analyses were conducted.

\section{Cumulative Contribution and Relevant Proportion of Companies}

According to Figure 2, it was obvious that the CCI for architectural and M\&E consultant companies were cumulating faster than clients and main contractors initially. According to the CCI of all the architectural consultant companies, the top $7 \%$ of companies had contributed about half of the total. The percentages for clients, main contractors and M\&E consultant companies are 20\%,16\% and 7\% respectively. As shown in Figure 2, the slope of the curve was decreasing as the cumulative CCI was added from the highest to the lowest. At first, the rate of change of cumulative CCI was rising faster than the rate of adding companies. Then after a point where the slope is 1 , it became lower. The point is defined as 'turning point' in this research. It could be found that a company whose CCI was added before the turning point had made a higher contribution than the average level. It is equal to the proportion that a company accounts for among others. The values of $\mathrm{X}$ axis and $\mathrm{Y}$ axis at the turning point of the four participant types are shown in Table 3. Generally, about 20 to 30 percent of companies in each participant type had contributed higher than the average level. Their cumulative CCI were between 60 and $75 \%$. 


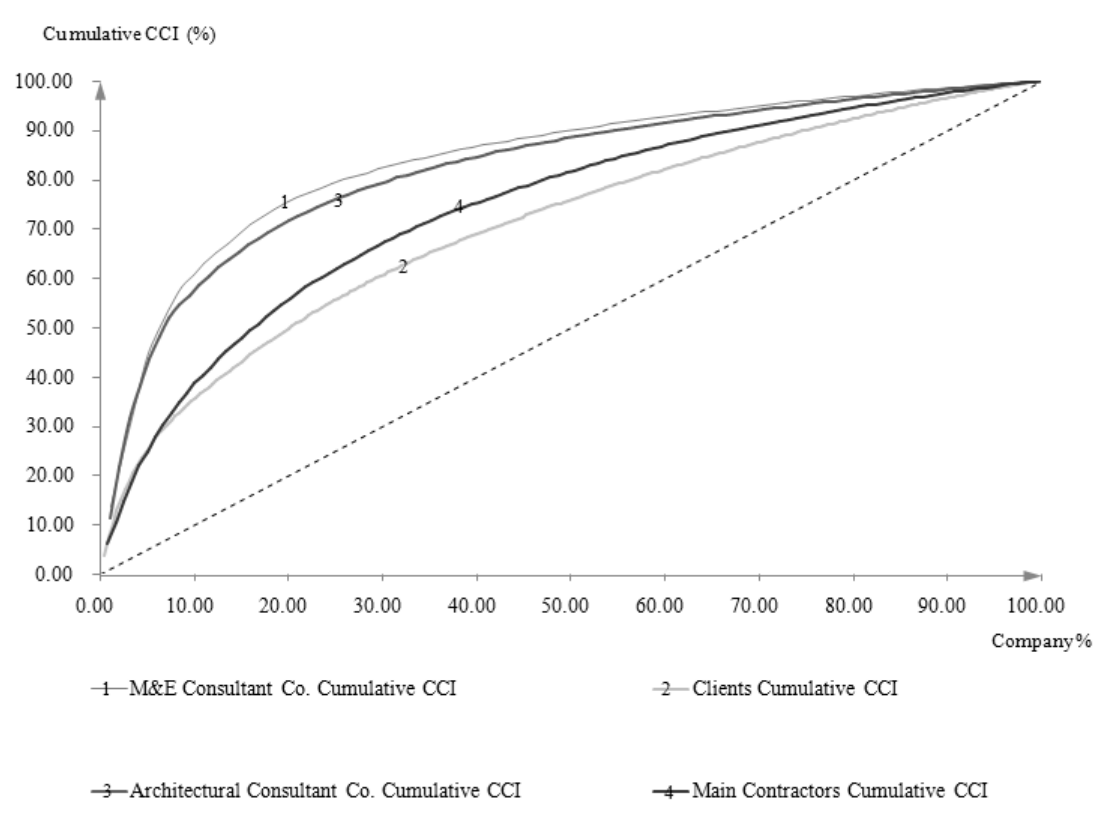

Figure 2: Cumulative contribution and relevant proportion of companies

Table 3: Turning point of cumulative CCI

\begin{tabular}{|l|c|c|}
\hline \multirow{2}{*}{\multicolumn{1}{|c|}{ Participant Category }} & \multicolumn{2}{|c|}{ Turning Point } \\
\cline { 2 - 3 } & \% Company & Cumulative CCI \\
\hline Clients & $28 \%$ & $59 \%$ \\
\hline Main Contractors & $31 \%$ & $68 \%$ \\
\hline Architectural Consultant Companies & $20 \%$ & $72 \%$ \\
\hline M\&E Consultant Companies & $20 \%$ & $75 \%$ \\
\hline
\end{tabular}

\section{Scatter Plots of FCI and ICI}

The scatter plots for four participants' ICI (as Y axis) and FCI (as X axis) are shown in Figure 3. The common feature of the four scatter plots was that there were several points in zone 1 and more points in zone 3. According to the interpretations of FIC and ICI, it meant that for the four types of participants, all of them had a few companies performing very well in participating in considerable numbers and space of green buildings, with good certification level. The difference was that clients had a few points in zone 2 (Figure 3a) and main contractors had some points in zone 4 (Figure 3b), but there were few or even nil points in zone 2 or 4 in the scatter plots of architectural and M\&E consultant companies (Figures $3 \mathrm{c}$ and $3 \mathrm{~d}$ ). Figure $3 \mathrm{a}$ showed that several clients (represented by points in zone 2) performed very well while evaluated by how much sustainable space they have created for Singapore, but did not get a higher score while being evaluated by how often they contributed, as they may have built only few sustainable buildings. Figure 3b showed that some main contractors (represented by points in zone 4) had participated in a considerable number of green buildings with relatively small GFA. 


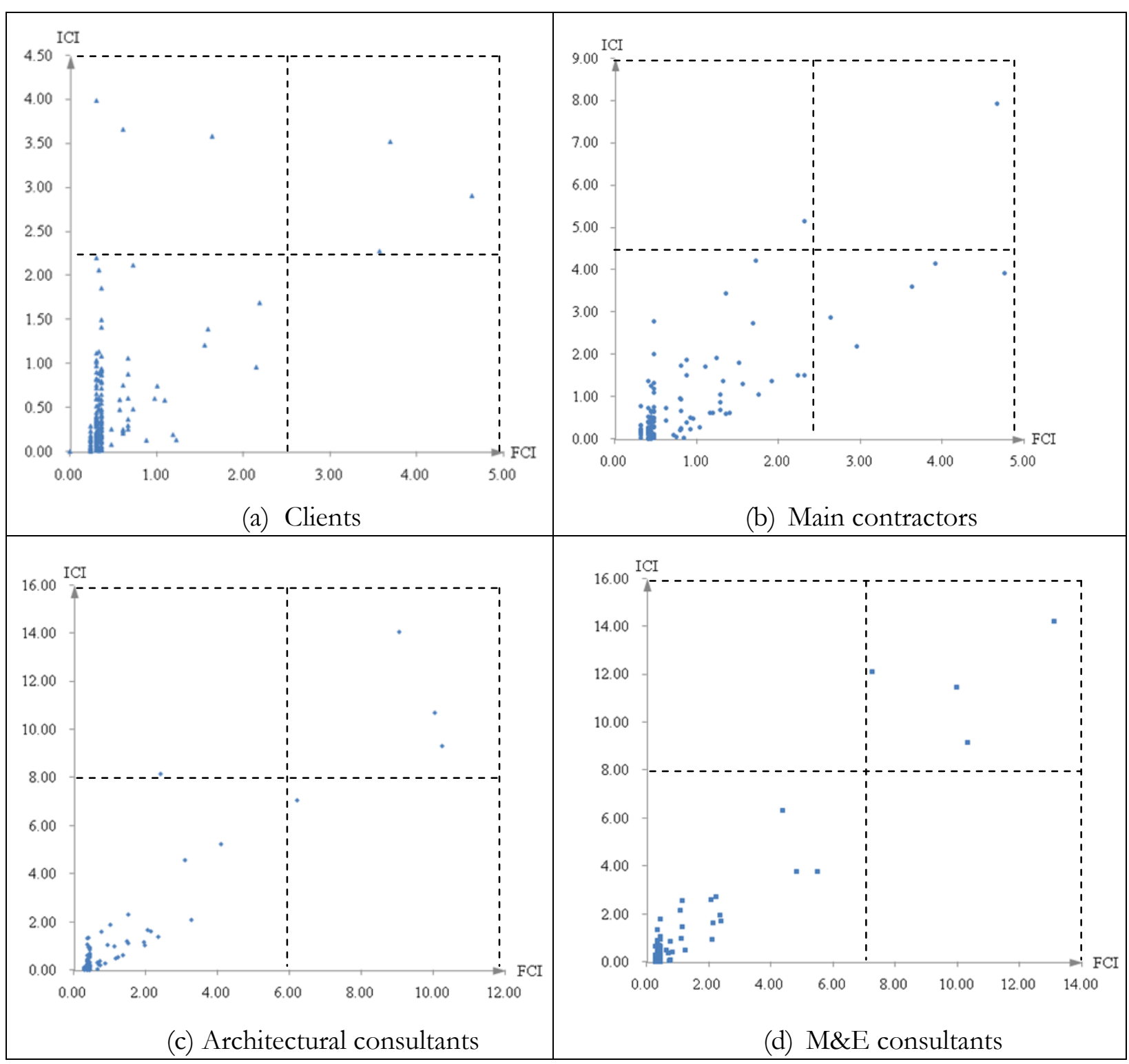

Figure 3: FCI-CCI scatter plots

\section{Analysis of the Companies with Higher Contributions}

The top ten companies with the highest CCI for each participant type were analyzed for a further investigation. The construction market in Singapore is open to international participation and as such the country where the company was originally founded was selected as an additional factor for comparison between local and international firms. Furthermore, there were quite a number of public institutions among the top ten clients. Some private clients in the top ten were well established commercial developers. Therefore, the two factors were included for the analysis of clients. The top ten ranked clients, main contractors, M\&E and architectural consultant companies are shown with codes in Table 4, 5, 6 and 7 respectively, according to their CCI rankings. The number of green buildings they had participated in and the rankings of their FCI and ICI are also shown in the tables. 
Table 4: Contribution index of top ten clients

\begin{tabular}{|c|c|c|c|c|c|c|c|c|c|}
\hline Clients & Company & Major Building & No. of GM & & CI & & CI & & 决 \\
\hline Code & Type & Types & Buildings & $\begin{array}{l}\text { CCI } \\
(\%)\end{array}$ & $\begin{array}{c}\text { Rank } \\
\text { CCI }\end{array}$ & $\begin{array}{l}\text { FCI } \\
(\%)\end{array}$ & $\begin{array}{c}\text { Rank } \\
\text { FCI }\end{array}$ & $\begin{array}{l}\text { ICI } \\
(\%)\end{array}$ & $\begin{array}{c}\text { Rank } \\
\text { ICI }\end{array}$ \\
\hline $\mathrm{C} 1$ & Private & Commercial - Mall & 14 & 3.77 & 1 & 4.63 & 1 & 2.91 & 5 \\
\hline $\mathrm{C} 2$ & Public & Commercial - Mall & 14 & 3.60 & 2 & 3.69 & 2 & 3.52 & 4 \\
\hline C3 & Public & $\begin{array}{l}\text { Institutional - } \\
\text { Education }\end{array}$ & 11 & 2.92 & 3 & 3.56 & 3 & 2.27 & 6 \\
\hline $\mathrm{C} 4$ & Public-Private & Comprehensive & 5 & 2.61 & 4 & 1.64 & 6 & 3.58 & 3 \\
\hline $\mathrm{C} 5$ & Private & Commercial - Mall & 1 & 2.15 & 5 & 0.31 & 32 & 3.99 & 1 \\
\hline C6 & Private & $\begin{array}{l}\text { Commercial - } \\
\text { Transportation }\end{array}$ & 2 & 2.14 & 6 & 0.61 & 15 & 3.66 & 2 \\
\hline $\mathrm{C} 7$ & Private & Commercial - Mall & 7 & 1.94 & 7 & 2.18 & 5 & 1.69 & 11 \\
\hline $\mathrm{C} 8$ & Public & $\begin{array}{l}\text { Institutional - } \\
\text { Education }\end{array}$ & 8 & 1.55 & 8 & 2.14 & 4 & 0.96 & 23 \\
\hline C9 & Public & $\begin{array}{l}\text { Commercial - } \\
\text { Transportation }\end{array}$ & 5 & 1.49 & 9 & 1.59 & 7 & 1.39 & 14 \\
\hline C10 & Public & $\begin{array}{l}\text { Institutional - } \\
\text { Education }\end{array}$ & 2 & 1.42 & 10 & 0.73 & 16 & 2.12 & 8 \\
\hline
\end{tabular}

*There are a total of 226 different clients participated in 317 GM building projects.

Table 5: Contribution index of top ten main contractors

\begin{tabular}{|clccccccc|}
$\begin{array}{c}\text { Main } \\
\begin{array}{c}\text { Contractors } \\
\text { Code }\end{array}\end{array}$ & Original Country & $\begin{array}{c}\text { No. of GM } \\
\text { Buildings }\end{array}$ & \multicolumn{2}{c}{ CCI } & \multicolumn{2}{c|}{ FCI } & \multicolumn{2}{c|}{ ICI } \\
\hline M1 & Japan & 11 & 6.30 & 1 & 4.67 & 2 & 7.93 & 1 \\
\hline M2 & Australia & 11 & 4.34 & 2 & 4.75 & 1 & 3.93 & 5 \\
\hline M3 & Japan & 9 & 4.03 & 3 & 3.91 & 3 & 4.15 & 4 \\
\hline M4 & South Korea & 5 & 3.73 & 4 & 2.31 & 7 & 5.15 & 2 \\
\hline M5 & Japan & 9 & 3.62 & 5 & 3.62 & 4 & 3.62 & 6 \\
\hline M6 & Japan-Singapore & 4 & 2.97 & 6 & 1.72 & 12 & 4.21 & 3 \\
\hline M7 & Singapore & 6 & 2.75 & 7 & 2.63 & 6 & 2.87 & 8 \\
\hline M8 & Singapore & 7 & 2.58 & 8 & 2.95 & 5 & 2.21 & 11 \\
\hline M9 & France & 3 & 2.40 & 9 & 1.35 & 17 & 3.45 & 7 \\
\hline M10 & Japan & 4 & 2.21 & 10 & 1.68 & 13 & 2.75 & 10 \\
\hline
\end{tabular}

*There are a total of 119 different main contractors participated in 241 GM building projects.

Table 4 showed that among the top ten clients, the public and private clients were sharing the market and fulfilling the responsibility on sustainability equally. Public clients were found to have come mainly from education and transportation sectors, while private clients mainly focused on commercial malls and office buildings. A special case was C5 with only one project. Nevertheless as it owned a very large landmark project with very good performance in sustainability, its 
ranking reached fifth place, which was very high. Table 5 showed that seven out of the top ten main contractors were foreign companies. Japanese main contractors dominated the non-residential building market with nearly half of the top ten. Local main contractors were not as competitive as foreign contractors. Table 6 showed that for M\&E consultant companies, the top ten made up more than a $65 \%$ contribution. Half of them were also foreign firms. Moreover, the top four M\&E consultant companies had preserved their rankings, remaining in the top four in both FCI and ICI. It indicated that several companies in the M\&E engineering sector maintained a clear advantage over others. It could be seen in Table 7 that the top three architectural consultant companies participated in more than $20 \mathrm{GM}$ buildings each, similar to M\&E companies.

Table 6: Contribution index of top ten M\&E consultant companies

\begin{tabular}{|c|c|c|c|c|c|c|c|c|}
\hline M\&E & Original Country & No. of GM & & & & & & \\
\hline $\begin{array}{l}\text { Consultant } \\
\text { Companies } \\
\text { Code }\end{array}$ & & Buildings & $\begin{array}{l}\text { CCI } \\
(\%)\end{array}$ & $\begin{array}{c}\text { Rank } \\
\text { CCI }\end{array}$ & $\begin{array}{l}\text { FCI } \\
(\%)\end{array}$ & $\begin{array}{c}\text { Rank } \\
\text { FCI }\end{array}$ & $\begin{array}{l}\text { ICI } \\
(\%)\end{array}$ & $\begin{array}{c}\text { Rank } \\
\text { ICI }\end{array}$ \\
\hline E1 & Singapore & 36 & 13.66 & 1 & 13.09 & 1 & 14.22 & 1 \\
\hline E2 & New Zealand & 25 & 10.73 & 2 & 9.98 & 3 & 11.48 & 3 \\
\hline E3 & Singapore & 28 & 9.75 & 3 & 10.32 & 2 & 9.17 & 4 \\
\hline E4 & USA & 20 & 9.69 & 4 & 7.26 & 4 & 12.12 & 2 \\
\hline E5 & Singapore & 11 & 5.35 & 5 & 4.36 & 7 & 6.34 & 5 \\
\hline E6 & Hong Kong & 15 & 4.64 & 6 & 5.51 & 5 & 3.77 & 6 \\
\hline E7 & Singapore & 12 & 4.29 & 7 & 4.83 & 6 & 3.76 & 7 \\
\hline E8 & USA & 6 & 2.49 & 8 & 2.24 & 10 & 2.74 & 8 \\
\hline E9 & Australia & 5 & 2.34 & 9 & 2.08 & 13 & 2.59 & 9 \\
\hline E10 & Singapore & 6 & 2.16 & 10 & 2.37 & 9 & 1.94 & 12 \\
\hline
\end{tabular}

*There are a total of 81 different M\&E consultant companies participated in 267 GM building projects.

Table 7: Contribution index of top ten architectural consultant companies

\begin{tabular}{|c|c|c|c|c|c|c|c|c|}
\hline Architectural & Original & No. of GM & \multicolumn{2}{|c|}{ CCI } & \multicolumn{2}{|c|}{ FCI } & \multicolumn{2}{|c|}{ ICI } \\
\hline $\begin{array}{l}\text { Consultant } \\
\text { Companies } \\
\text { Code }\end{array}$ & Country & Buildings & $\begin{array}{l}\text { CCI } \\
(\%)\end{array}$ & $\begin{array}{c}\text { Rank } \\
\text { CCI }\end{array}$ & $\begin{array}{l}\text { FCI } \\
(\%)\end{array}$ & $\begin{array}{c}\text { Rank } \\
\text { FCI }\end{array}$ & $\begin{array}{l}\text { ICI } \\
(\%)\end{array}$ & $\begin{array}{c}\text { Rank } \\
\text { ICI }\end{array}$ \\
\hline A1 & Singapore & 23 & 11.55 & 1 & 9.05 & 3 & 14.05 & 1 \\
\hline A2 & Singapore & 27 & 10.36 & 2 & 10.04 & 2 & 10.69 & 2 \\
\hline A3 & Singapore & 28 & 9.78 & 3 & 10.24 & 1 & 9.31 & 3 \\
\hline A4 & Singapore & 17 & 6.63 & 4 & 6.20 & 4 & 7.06 & 5 \\
\hline A5 & UK \& Asia & 6 & 5.28 & 5 & 2.40 & 8 & 8.15 & 4 \\
\hline A6 & Singapore & 11 & 4.66 & 6 & 4.08 & 5 & 5.24 & 6 \\
\hline A7 & Hong Kong & 8 & 3.83 & 7 & 3.08 & 7 & 4.57 & 7 \\
\hline A8 & Singapore & 9 & 2.68 & 8 & 3.26 & 6 & 2.09 & 9 \\
\hline A9 & Singapore & 4 & 1.91 & 9 & 1.50 & 14 & 2.31 & 8 \\
\hline A10 & Singapore & 7 & 1.87 & 10 & 2.13 & 10 & 1.61 & 12 \\
\hline
\end{tabular}

*There are a total of 95 different architectural consultant companies participated in 268 GM building projects. 


\section{Discussion of the Results through Interviews}

Regarding the construction of the index and the analysis based on it at company level, interviews with five experts were undertaken to verify the suitability of the index to assess companies' green efforts and the analysis results. Three of the interviewees are officials from the government department in charge of the Green Mark scheme in Singapore. The fourth interviewee is an academic from a well-recognized university with the focus on sustainability of buildings. The fifth interviewee is a facilities manager from a leading corporation that has been developing and operating several landmark properties in Singapore. The questions asked in the interviews are as follows:

Part 1 Suitability of the index to assess companies' green efforts and applications of the index

1. Is the selection of three indicators, namely, quantity, space and quality of the green buildings that one company has participated in appropriate for the comprehensive evaluation of its contribution in the green building industry?

2. Do you think the rankings of companies' contribution index would motivate them to environmentally friendly decisions and actions in the green building industry?

3. What other situations or purposes do you think the index could be useful for the governments/researchers/companies?

Part 2 Verification of the analysis results of the index at company level

1. According to the analysis results in cumulative contribution and relevant proportion of companies, the concentration of contribution to the green building industry is higher for the architectural and M\&E consultant companies as compared to that for clients and main contractors which is found to be relatively widespread (Figure 2 and Table 3). Do you think that several large firms are dominating the green building industry in architectural or M\&E consultancy works?

2. According to the analysis results of the companies with higher contributions, public and private clients are equally taking the lead towards sustainability in non-residential buildings sector (Table 4). Do think it is reasonable that private clients have also been taking a lead in promoting sustainability?

3. According to the analysis results of the companies with higher contributions, foreign main contractors, especially Japanese companies, are playing an important role in the green building industry (Table 5). Do you think this is true for the current situations in the industry?

The interviewees' response and discussion of the results are as below:

Part 1-1. The interviewees agreed that the index had adopted a comprehensive view towards recognizing companies' green efforts. Generally, the quantity and certification levels of the green buildings would be considered. But the inclusion of GFA in the index was new and reasonable since buildings with larger space would normally require more energy consumption. If a developer has been awarded the 'Platinum' level for a large scale building, the green efforts such as the energy saved, are more than that of one small building 'Platinum' certified. It would be fairer to add the space indicator into the assessment. 
Part 1-2. As mentioned by the interviewees, the index could be used as a criterion to award recognition so as to motivate the participants. Rankings of companies' contribution index could lead to direct impressions about their efforts in the green building industry. Comparisons of the rankings with others would raise companies' sense of being competitive in sustainability.

Part 1-3. The interviewees commented that the index was useful for the government to know which were the companies had not been pushing their limit to aim for the higher levels of Green Mark rating. Companies that are doing very well could be identified by the government as model companies for others to follow, with the help of CCI. Some mentioned that the rankings based on CCI could help companies be aware of their sustainability status compared to others. This could be quite helpful for them to adjust their strategies on sustainability targets, such as investing more if their current rankings were lower than what was expected.

Part 2-1. It was a fact that those architectural and M\&E consultant companies were actually dominating the whole building industry. Some had developed their professional capability in Singapore very well and had already been successful for many years in overseas market such as China and the Middle East. Architectural and M\&E consultant companies' technology and knowledge on green buildings were the ones that Singapore exported overseas first.

Part 2-2. The government officials acknowledged that the plan was to let the public sector take the lead by building the required capability in the industry and spur others in the private sector to follow. However, after years of promoting Green Mark, there was an increasing awareness of the importance of green building among private clients. As a result of their experience, some private clients had enjoyed benefits such as saving on energy bills and higher profit from rentals. That was the reason private companies, especially the large ones, had been active in enhancing the sustainability of their buildings.

Part 2-3. It is a well-known fact that some foreign main contractors were sharing a large market proportion in Singapore, not just for green building. These companies usually would have developed their capability, especially for large projects, in their home country. Their strong capability and track record placed them as competitive participants in an open market where natural barriers like language were not an obstacle. In contrast, the local main contractors had limited opportunity to 'grow' in their home country.

\section{Conclusions}

This paper has introduced a contribution index that considers numbers, GFA and certification levels of buildings to assess companies' green efforts. The index has been verified to be a suitable way to make comprehensive assessments. Governments can use it as a criterion for awarding recognition to participants to motivate them to build environmentally friendly buildings. Companies may adjust their sustainability strategies and allocate resources more optimally according to their contribution index rankings. A case study of Singapore has been conducted to apply the index and some findings have been concluded. First, the public and private clients have been equally leading the building industry towards sustainability. Second, for the main contractors, foreign firms have had a larger share of the contribution. When it comes to the other participants, namely architectural and M\&E consultant companies, the clear trend has been for some large or reputable players to dominate the market. 
Researchers may apply the method in their country or region with the weights suggested in Table 1 or adjusted weights based on their specific needs. The conversion rates between the weights in different GBCS (as shown in Table 1) can be studied according to their assessment criteria and methods. The rates will allow researchers to evaluate companies' total green efforts while considering other projects located in multiple regions or countries where more than one GBCS are involved. Furthermore, software incorporated with CCI and updated data can be developed to enable researchers to study the dynamic changes and trends in the green building industry. For example, in the case study, the foreign main contractors are currently dominating the green building market. But the index will change with updated data. If more Singaporean companies are ranked in the top ten in Table 5, a trend for local main contractors to play a more important role in the green building industry can be presumed.

\section{Acknowledgements}

The authors wish to thank the anonymous referees for their constructive comments. The work conducted for publication was wholly funded by the National University of Singapore [grant number R296000144646].

\section{Reference}

Ali, H.H. and Al Nsairat, S.F., 2009. Developing a green building assessment tool for developing countries - Case of Jordan. Building and Environment, 44(5), pp.1053-64. doi: http://dx.doi.org/10.1016/j.buildenv.2008.07.015

Baird, G., 2009. Incorporating User Performance Criteria into Building Sustainability Rating Tools (BSRTs) for Buildings in Operation. Sustainability, 1(4), pp.1069-86. doi: http://dx.doi.org/10.3390/su1041069

Building and Construction Authority (BCA), 2005. BCA Green Mark Awards 2005. [online] Available at: http://www.bca.gov.sg/greenmark/others/gm2005.pdf [Accessed 10 December 2014].

Building and Construction Authority (BCA), 2006. BCA Green Mark Awards 2006. [online] Available at: http://www.bca.gov.sg/greenmark/others/gm2006.pdf [Accessed 10 December 2014].

Building and Construction Authority (BCA), 2007. BCA Green Mark Awards 2007. [online] Available at: http://www.bca.gov.sg/greenmark/others/gm2007.pdf [Accessed 10 December 2014].

Building and Construction Authority (BCA), 2008. BCA Green Mark Awards 2008. [online] Available at: http://www.bca.gov.sg/greenmark/others/gm2008.pdf [Accessed 10 December 2014].

Building and Construction Authority (BCA), 2009. BCA Green Mark Awards 2009. [online] Available at: http://www.bca.gov.sg/greenmark/others/gm2009.pdf [Accessed 10 December 2014].

Building and Construction Authority (BCA), 2010a. BCA Green Mark Awards 2010a. [online] Available at: http://www.bca.gov.sg/greenmark/others/gm2010.pdf [Accessed 10 December 2014].

Building and Construction Authority (BCA), 2010b. BCA Green Mark for New Residential Buildings Version RB/4.0. Singapore: Building \& Construction Authority.

Building and Construction Authority (BCA), 2011. BCA Green Mark Awards 2011. [online] Available at: http://www.bca.gov.sg/greenmark/others/gm2011.pdf [Accessed 10 December 2014].

Building and Construction Authority (BCA), 2012. BCA Green Mark Awards 2012. [online] Available at: http://www.bca.gov.sg/greenmark/others/gm2012.pdf [Accessed 10 December 2014].

BEAM Society Ltd., 2012. BEAM Plus New Buildings (Version 1.2). [online] Available at: http://www.beamsociety.org.hk/files/BEAM Plus For New Buildings Version 1 2.pdf $\quad$ [Accessed 1 December 2014]. 
BRE Global Ltd., 2011. BREEAM New Construction - Non-Domestic Buildings Technical Manual (SD5073-2.0:2011) [online]

Available

at: http://www.breeam.org/breeamGeneralPrint/breeam non dom manual 3 0.pdf $[$ Accessed 1 December 2014].

BRE Global Ltd., 2014. The World's Leading Design and Assessment Method for Sustainable Buildings. [online] Available at: http://www.breeam.org [Accessed 5 December 2014].

Canada Green Building Council (CaGBC), 2014. Canada Green Building Council [online] Available at: http://www.cagbc.org [Accessed 5 December 2014].

Chew, K.C., 2010. Singapore's strategies towards sustainable construction. The IES Journal Part A: Civil \& Structural Engineering, 3(3), pp.196-202. doi: http://dx.doi.org/10.1080/19373260.2010.491641

Chu, T-J., Chang, A-P., Hwang, C-L., and Lin J-D., 2014. Intelligent Green Buildings Project Scope Definition Using Project Definition Rating Index (PDRI). Procedia Economics and Finance, 18, pp.17-24. doi: http://dx.doi.org/10.1016/S2212-5671(14)00908-3

Cole, R.J., 1999. Building environmental assessment methods: clarifying intentions. Building Research \& Information, 27(4-5), pp.230-46. doi: http://dx.doi.org/10.1080/096132199369354

Deng, S-M. and Burnett, J., 2000. A study of energy performance of hotel buildings in Hong Kong. Energy and Buildings, 31(1), pp.7-12. doi: http://dx.doi.org/10.1016/S0378-7788(98)00067-X

Ding, G.K.C., 2008. Sustainable construction - The role of environmental assessment tools. Journal of Environmental Management, 86(3), pp.451-64. doi: http://dx.doi.org/10.1016/j.jenvman.2006.12.025

Gabzdylova, B., Raffensperger, J.F. and Castka, P., 2009. Sustainability in the New Zealand wine industry: drivers, stakeholders and practices. Journal of Cleaner Production, 17(11), pp.992-98. doi: http://dx.doi.org/10.1016/j.jclepro.2009.02.015

Green Building Council Australia (GBCA), 2012. Green Star Communities - Rating Tool [online]. Australia: GBCA [online] Available at: https://www.gbca.org.au/green-star/green-star-communities/rating-tool/_Accessed 1 December 2014].

Green Building Council Brasil (GBCBrasil), 2014. Green Building Council Brasil [online] Available at: http://www.expogbcbrasil.org.br [Accessed 5 December 2014].

Green Building Council South Africa (GBSCA), 2014. Green Building Council South Africa [online] Available at: https://www.gbcsa.org.za [Accessed 10 December 2014].

Green Mark, 2014. BCA Green Mark [online] Available at: http://www.greenmark.sg/ [Accessed 5 December 2014]. Housing and Develoment Board (HDB), 2014. HDB Annual Report 2013/14 [online] Available at: http://www10.hdb.gov.sg/eBook/ar2014/keystatistics/index.html [Accessed 10 December 2014].

Häkkinen, T. and Belloni, K., 2011. Barriers and drivers for sustainable building. Building Research \& Information, 39(3), pp.239-55. doi: http://dx.doi.org/10.1080/09613218.2011.561948

Holt, G.D., Olomolaiye, P.O. and Harris, F.C., 1994. Factors influencing U.K. construction clients' choice of contractor. Building and Environment, 29(2), pp.241-48. doi: http://dx.doi.org/10.1016/0360-1323(94)90074-4

India Green Building Council (IGBC), 2014. India Green Building Council [online] Available: https://www.igbc.in [Accessed 10 Dec 2014].

Ives, M., 2013. Singapore Takes the Lead in Green Building in Asia [online]. Environment 360, Yale School of Forestry \& Environmental Studies, Yale Aniversity. Available at: http://e360.yale.edu/feature/singapore takes the lead in green building in asia/2720/ [Accessed 20 December 2014].

Kauffman, J., 2006. To LEED or Not to Lead. Log, 8(Summer), pp.13-20.

Kibert, C.J., 2008. Sustainable Construction: Green Building Design and Delivery. New Jersey: John Wiley \& Sons, Inc. 
Kubba, S., 2012. Handbook of Green Building Design and Construction: LEED, BREEAM, and Green Globes. Boston: Butterworth-Heinemann. doi: http://dx.doi.org/10.1016/B978-0-12-385128-4.00025-1

Lee, W.L. and Burnett, J., 2008. Benchmarking energy use assessment of HK-BEAM, BREEAM and LEED. Building and Environment, 43(11), pp.1882-91. doi: http://dx.doi.org/10.1016/j.buildenv.2007.11.007

Love, P., Niedzweicki, M., Bullen, P. and Edwards, D., 2012. Achieving the Green Building Council of Australia's World Leadership Rating in an Office Building in Perth. Journal of Construction Engineering and Management, 138(5), pp.652-60. doi: http://dx.doi.org/10.1061/(ASCE)CO.1943-7862.0000461

Ministry of Housing and Urban-Rural Development (MHURD), 2014. GB/T 50378-2014 Assessment Standard for Green Building. China: MHURD.

Nardo, M., Saisana, M., Saltelli, A., Tarantola, S., Hoffman, A. and Giovannini, E., 2005. Handbook on Constructing Composite Indicators: Methodology and User Guide. OECD Statistics Working Papers 2005/03. OECD Publishing. doi: http://dx.doi.org/10.1787/533411815016

O'Hare, W. and Gutierrez, F., 2012. The Use of Domains in Constructing a Comprehensive Composite Index of Child Well-Being. Child Indicators Research, 5(4), pp.609-29. doi: http://dx.doi.org/10.1007/s12187-012-9138-6

Paul, W.L. and Taylor, P.A., 2008. A comparison of occupant comfort and satisfaction between a green building and a conventional building. Building and Environment, 43(11), pp.1858-70. doi: http://dx.doi.org/10.1016/j.buildenv.2007.11.006

Raab, R.A. and Kotamraju, P., 2006. The Efficiency Of The High-Tech Economy: Conventional Development Indexes Versus A Performance Index. Journal of Regional Science, 46(3), pp.545-62. doi: http://dx.doi.org/10.1111/j.1467-9787.2006.00452.x

Rogge, N., 2012. Undesirable specialization in the construction of composite policy indicators: The Environmental Performance Index. Ecological Indicators, 23, pp.143-54. doi: http://dx.doi.org/10.1016/j.ecolind.2012.03.020

Russia Green Building Council (RuGBC), 2014. Green Building Council Russia [online] Available at: http://www.rugbc.org [Accessed 10 December 2014].

Sagar, A.D. and Najam, A., 1998. The human development index: a critical review. Ecological Economics, 25(3), pp.249-64. doi: http://dx.doi.org/10.1016/S0921-8009(97)00168-7

Saisana, M., Tarantola, S., 2002. State-of-the-art Report on Current Methodologies and Practices for Composite Indicator Development, Institute for the Protection and the Security of the Citizen, Technological and Economic Risk Management Unit. Italy: European Commission, Joint Research Centre [online] Available at: http://citeseerx.ist.psu.edu/viewdoc/download?doi=10.1.1.402.5612\&rep=rep1\&type=pdf.

Shohet, I.M., 2003. Building evaluation methodology for setting maintenance priorities in hospital buildings. Construction Management and Economics, 21, pp.681-92. doi: http://dx.doi.org/10.1080/0144619032000115562

Siew R.Y.J., Balatbat, M.C.A. and Carmichael, D.G., 2013. A review of building/infrastructure sustainability reporting tools (SRTs). Smart and Sustainable Built Environment, 2(2), pp.106-39. doi: http://dx.doi.org/10.1108/sasbe-03-2013-0010

Soebarto, V.I. and Williamson, T.J., 2001. Multi-criteria assessment of building performance: theory and implementation. Building and Environment, 36(6), pp.681-90. doi: http://dx.doi.org/10.1016/S0360-1323(00)00068-8

Tatari, O. and Kucukvar, M., 2011. Cost premium prediction of certified green buildings: A neural network approach. Building and Environment, 46(5), pp.1081-86. doi: http://dx.doi.org/10.1016/i.buildenv.2010.11.009

United States Green Building Council (USGBC), 2009. LEED 2009 for New Construction and Major Renovations Rating System [online] Available at: http://www.usgbc.org/Docs/Archive/General/Docs5546.pdf [Accessed 1 December 2014].

United States Green Building Council (USGBC), 2014. United States Green Building Council [online] Available at: 
http://www.usgbc.org [Accessed 10 December 2014].

Wong, J.M.W., Ng, S.T. and Chan, A.P.C., 2010. Strategic planning for the sustainable development of the construction industry in Hong Kong. Habitat International, 34(2), pp.256-63. doi: http://dx.doi.org/10.1016/j.habitatint.2009.10.002

Ye, L., Cheng, Z., Wang, Q., Lin, W. and Ren, F., 2013. Overview on Green Building Label in China. Renewable Energy, 53, pp.220-29. doi: http://dx.doi.org/10.1016/j.renene.2012.11.022 